\title{
The effects of zinc supplementation on the TNF- $\alpha$ profile and diarrhea in severely malnourished children of low income family
}

\author{
Suryani As'ad, Irawan Yusuf ${ }^{f}$
}

\begin{abstract}
Abstrak
Defisiensi seng (Zn) mempunyai peran yang besar pada proses tumbuh-kembang. Hal ini terutama akan berdampak pada anak-anak kekurangan gizi. Zn penting dalam kekebalan tubuh baik yang bersifat lokal maupun sistemik. Tujuan penelitian ini adalah untuk menilai dampak suplementasi Zn pada sitokin TNF- $\alpha$ dan diare pada balita dengan malnutrisi berat dari keluarga berpendapatan rendah. Desain penelitian adalah jenis controlled randomized double blind pre-test post-test pada kelompok anak berusia 12-59 bulan. Anak-anak diberi makanan biasa dan dibagi menjadi 2, kelompok kontrol $(n+60)$ dan kelompok intervensi yang diberikan makanan mengandung $15 \mathrm{mg} / \mathrm{ml} \mathrm{Zn}$. Kadar Zn diukur menggunakan atomic absorption spectrophotometer (AAS), sedangkan TNF- $\alpha$ menggunakan ELISA. Data masukan makanan dikumpulkan melalui cara wawancara makanan dalam 24-jam. Hasil penelitian menunjukkan adanya peningkatan kadar Zn serum yang bermakna dan penurunan kadar TNF- $\alpha$ serta penurunan lama dan frekuensi diare setelah intervensi. Kadar Zn meningkat 87,0\% pada kelompok intervensi, sedangkan pada kelompok kontrol peningkatan hanya sebesar 19,6\%. Selain itu, terdapat penurunan bermakna baik pada kadar TNF- $\alpha$ serum maupun feses setelah intervensi ( $p<0.05$ ). Beratnya gejala maupun lamanya diare berkurang secara bermakna pada kelompok intervensi $(p<0.001)$. Dari hasil penelitian ini dapat disimpulkan bahwa pemberian suplemen Zn dapat mengurangi lama dan beratnya diare melalui peningkatan kekebalan tubuh, terutama imunitas lokal yang menggunakan TNF- $\alpha$ sebagai biomarker. (Med J Indones 2003; 12: 247-51)
\end{abstract}

\begin{abstract}
Zinc deficiency has a great impact on growth and development, especially in malnourished children. Zinc is important in both local and systemic immunity. The aim of this study was to assess the impact of zinc supplementation on the cytokine, tumor necrosis factor $\alpha$ (TNF$\alpha$ ), and diarrhea in severely undernourished under-five children of low-income families. A randomized double blind pre-test post-test controlled design was selected. A group of 12-59 month-old children were given local food, and treated as control group (n=60), and another group $(n=60)$ were given local food with $15 \mathrm{mg} / 5 \mathrm{ml}$ zinc as intervention group. Zinc concentration was measured by atomic absorption spectrophotometer $(A A S)$, and TNF- $\alpha$ concentration was determined by ELISA. Data on nutrient intakes were collected using 24-hour food recall method. The result of the study showed that after zinc intervention, zinc serum increased significantly, and TNF- $\alpha$ concentration decreased along with reduction of the duration and frequency of diarrhea. Zinc concentration increased $87.0 \%$ in the intervention group, while in the control group the increase was only 19.6\%. There was a significant reduction of both serum and fecal $T N F-\alpha$ concentration after intervention $(p<0.05)$. Severity and duration of diarrhea were reduced significantly in the intervention group compared to the control group $(p<0.001)$. It was concluded that zinc intervention reduced the duration and severity of diarrhea through improvement of immunity, especially local immunity with TNF- $\alpha$ as biomarker. (Med J Indones 2003; 12: 247-51)
\end{abstract}

Keywords: undernourished children, zinc supplementation, diarrhea, TNF- $\alpha$.

Undernutrition and infection are interrelated factors that affect health status of children and is currently

\footnotetext{
* Department of Nutrition Faculty of Medicine, Hasanuddin University, Makassar, Indonesia

${ }^{f}$ Department of Physiology Faculty of Medicine and Division of Biotechnology Research Center, Hasanuddin University, Makassar, Indonesia
}

becoming an intensive research area. Undernutrition might be a primary nutritional inadequacy due to low family food security, or secondary to infection, including diarrhea. Among children in developing countries, diarrhea, especially those of prolonged duration and frequency, is an important cause of growth retardation and death. Diarrhea which usually recovers within a few days in healthy children, persists longer in children with undernutrition along with impaired cellular immunity. ${ }^{1,2}$ 
Recently, zinc deficiency has been recognized as an important factor in immune status and is related to increased risk of intestinal and respiratory infections. ${ }^{3,4}$ The specific mechanisms of how zinc modulates mucosal immune response and increases susceptibility to intestinal infection is still unclear.

Zinc plays important role in intestinal mucosal growth. Several reports have shown that zinc deficiency causes atrophy of the intestinal mucosa. This in turn decreases the absorption surface of the small intestines significantly and causes diarrhea. Experiments in mice deficient of zinc has shown that apoptosis occurring in the enterocytes was the basic pathological process that causes atrophy. ${ }^{5}$ Zinc deficiency decreases production of insulin like-growth factor-1 (IGF-1) and causes atrophy of the intestinal villi and damage the tight junction increasing membrane permeability. This interrelationship proves the dynamic link between the integrity of intestinal structure and zinc status. ${ }^{6}$

Zinc modulates many aspects of the immune system including production of cytokines, such as tumor necrosis factor- $\alpha$ (TNF- $\alpha$ ), interferon- $\gamma$ (IFN- $\gamma$ ), interleukin-6 (IL-6) and other cytokines. ${ }^{7}$ TNF- $\alpha$ as a proinflamatory cytokine has been reported to induce apoptosis in animal experiments by producing free radicals. ${ }^{8}$ Zinc has been reported as an antioxidant that is able to protect the integrity of the cell through immune response activation. ${ }^{9}$

The objective of the study was to investigate the effect of zinc supplementation on the duration and frequency of diarrhea and to correlate the effect with TNF- $\alpha$ concentration in a community-based, double blind, placebo-controlled trial.

\section{METHODS}

\section{Study population}

The study was conducted in 3 areas of Makassar, a city in South Sulawesi, with an urban population of low socioeconomic status. It was held between May and December 2001. A total of 120 undernourished children aged 12-59 months (60 in the control and 60 in the intervention group) were selected through an established household-surveillance system. The Ethical Review Committee in Hasanuddin University approved the study, and written informed consent was obtained from the parents of each child.

\section{Intervention techniques}

Underweight children were randomly allocated by using a random table. These children were to receive complete local food and $5 \mathrm{ml}$ of liquid with zinc citrate containing $15 \mathrm{mg}$ of elemental zinc (intervention group) and similar complete local food and liquid without zinc (control group) every day for 8 weeks. Both liquids contained sorbitol, flavors, and preservative; and were indistinguishable in both appearance and taste. Both were prepared and coded by the Department of Pharmacy, Faculty of Natural Sciences and Mathematics, Hasanuddin University. The codes of supplements were unknown to both participants and researches and were opened only after data editing and cleaning were completed. The local food was food containing carbohydrate, protein, fat, vitamin and mineral sources. The raw materials for the food were available locally, easy to find, not expensive and acceptable by the children.

The serum zinc and TNF- $\alpha$ concentration were measured 8 weeks before and 8 weeks after intervention. The study subjects were followed daily by investigators and well-trained nutritionists for assessment of compliance and morbidity of diarrhea starting 2 months before, during, and 2 months after intervention. Information of feeding practices was collected daily.

\section{Data collection and laboratory procedures}

During daily visits, detailed history of diarrhea and other illnesses were recorded. The children were observed for duration and frequency of diarrhea. Diarrhea was defined as the passage of three or more watery stools in 24 hours. The frequency of diarrhea was defined as frequency of watery stools in 24 hours. Duration of diarrhea was defined as the number of days of having diarrhea, for two month before and two months after the intervention.

During weekly visits, weight was measured to the nearest 10 gr on a beam-balance scale (Seca 725:Seca, Hamburg, Germany) that was regularly calibrated. Recumbent length or height was measured to the nearest $0.1 \mathrm{~cm}$ on a length board or microtoice. The mean of two measurements was recorded as the observed value for all indexes.

One day before and one day after the intervention, non-fasting blood specimens were obtained by antecubital venipuncture for zinc and TNF- $\alpha$ serum 
concentration. Serum was separated soon after collection and stored at $-20^{\circ} \mathrm{C}$ until analysis. Zinc concentration was measured by atomic absorption spectrophotometry (AAS), and TNF- $\alpha$ concentration determined by Sandwich ELISA, using Quantikine Human TNF- $\alpha$. (R\&D, Minneapolis, USA). ${ }^{11}$ Standard curves were established for both measurements.

\section{Statistical analysis}

Baseline comparisons of continuous variables between the intervention and the control groups were tested with student's $t$ test. Differences between the means of not normally distributed data were tested by Wilcoxon Sign Rank test. Pearson correlation was calculated to measure the relationship between variables. The effect of zinc intervention on serum zinc concentration, duration and severity of diarrhea, and serum and fecal TNF- $\alpha$ concentration were measured by linear multi-regression analysis. $P$ values of $<0.05$ were considered statistically significant. The results were presented as means $( \pm$ SDs $)$ unless otherwise stated. All statistical analyses were conducted with SPSS for Windows (version 10.01, SPSS, Chicago) and EpiInfo. ${ }^{11}$

\section{RESULTS}

A total of 120 children (60 in the control and 60 in the intervention group) participated in the study. Compliance with supplement consumption was more than $99 \%$ of total days. No differences in compliance were observed between two groups. The base-line characteristics of children in the two groups did not differ (Table 1). At base-line, 67.5\% of the children had serum zinc concentrations of less than 10.7 $\mu \mathrm{mol} / \mathrm{L}$, and were considered to be zinc deficient.

\section{Serum Zinc Concentration}

After 8 weeks supplementation, the intervention group significantly had higher zinc concentration than did the control group (19.17 \pm 9.8 compared to $12.68 \pm 5.8 \mu \mathrm{mol} / \mathrm{L} ;(\mathrm{p}=0.001)$. Zinc supplementation reduced the prevalence of zinc deficiency to $9.4 \%$ in the intervention group compared to $34.4 \%$ in the control group $(\mathrm{p}<0.05)$. Serum zinc concentration increased by $87.0 \%$ in the intervention group compared to $19.6 \%$ in the control group.
Tabel 1. Some characteristics of the subjects before intervention

\begin{tabular}{lcc}
\hline & \multicolumn{2}{c}{ Mean and standard deviation } \\
\cline { 2 - 3 } & $\begin{array}{c}\text { Intervention } \\
(\mathrm{N}=60)\end{array}$ & $\begin{array}{c}\text { Control } \\
(\mathrm{N}=60)\end{array}$ \\
\hline & & \\
Age (months) & $27.16 \pm 11$ & $27.27 \pm 10$ \\
Weight at birth (gr) & $2697 \pm 22$ & $2727 \pm 23$ \\
Body weight (gr) & $8170 \pm 1332$ & $8360 \pm 1296$ \\
Height (cm) & $78.71 \pm 7.5$ & $79.97 \pm 7.49$ \\
WAZ-Score & $-3.34 \pm 0.63$ & $-3.30 \pm 0.86$ \\
Duration of breast feeding & $12.4 \pm 3.1$ & $12.3 \pm 2.9$ \\
$\quad$ (mo) & & \\
Duration of diarrhea (day) & $4.79 \pm 3.5$ & $4.20 \pm 2.36$ \\
Severity of diarrhea (x/day) & $5.78 \pm 2.9$ & $5.43 \pm 2.7$ \\
Serum zinc (umol/liter) & $10.25 \pm 5.4$ & $10.60 \pm 4.94$ \\
TNF- $\alpha$ (pg/mL): & & \\
- Serum & $340.8 \pm 305.6$ & $258.4 \pm 54.8$ \\
- Feces & $49.8 \pm 38.4$ & $44.5 \pm 37.3$ \\
\hline
\end{tabular}

Table 2. Zinc serum before and after intervention

\begin{tabular}{|c|c|c|c|}
\hline & \multicolumn{2}{|c|}{$\begin{array}{l}\text { Mean and standard deviation } \\
\text { of serum zinc } \\
(\mu \mathrm{mol} / \mathrm{L})\end{array}$} & \multirow[t]{2}{*}{$\mathrm{p}$} \\
\hline & $\begin{array}{c}\text { Before } \\
\text { intervention }\end{array}$ & $\begin{array}{c}\text { After } \\
\text { intervention }\end{array}$ & \\
\hline $\begin{array}{l}\text { Intervention } \\
\qquad(\mathrm{N}=60)\end{array}$ & $10.25 \pm 5.40$ & $19.17 \pm 9.85$ & 0.0001 \\
\hline $\begin{array}{l}\text { Control } \\
\qquad(\mathrm{N}=60)\end{array}$ & $10.60 \pm 4.95$ & $12.68 \pm 5.86$ & 0.001 \\
\hline
\end{tabular}

\section{Serum and Fecal TNF- $\alpha$ Concentration}

Significant decreases in serum TNF- $\alpha$ level were observed in the intervention and the control groups (Table 3). Mean concentrations of serum TNF- $\alpha$ before and after zinc supplementation were $340.8 \pm 305.6$ $\mathrm{pg} / \mathrm{ml}$ and $22.5 \pm 20.5 \mathrm{pg} / \mathrm{ml}$ for the intervention group and $358.4 \pm 544.8 \mathrm{pg} / \mathrm{ml}$ and $83.6 \pm 48.1 \mathrm{pg} / \mathrm{ml}$ for the control group.

After 8 weeks intervention, fecal TNF- $\alpha$ levels were decreased significantly in the intervention group (49.8 $\pm 38.3 \mathrm{pg} / \mathrm{mL}$ and $11.8 \pm 4.9 \mathrm{pg} / \mathrm{mL} ; \mathrm{p}=0.000$ ), where as in the control group, it was not significantly different $(44.5 \pm 37.3 \mathrm{pg} / \mathrm{mL}$ and $43.4 \pm 39.8 \mathrm{pg} / \mathrm{mL}$; $\mathrm{p}=0.390)$. 
Table 3. TNF $\alpha$ before and after intervention

\begin{tabular}{lccc}
\hline & \multicolumn{2}{c}{ Mean and standard deviation } & P \\
\cline { 2 - 3 } & Intervention & Control & \\
\hline TNF $\alpha$ serum & & & \\
$\quad$ Before & $340.8 \pm 305.6$ & $358.4 \pm 54.8$ & 0.106 \\
After & $22.5 \pm 20.5$ & $83.6 \pm 34.6$ & 0.069 \\
& & & \\
TNF $\boldsymbol{\alpha}$ feces & & & \\
$\quad$ Before & $49.8 \pm 38.35$ & $44.5 \pm 37.3$ & 0.423 \\
$\quad$ After & $11.8 \pm 4.9$ & $43.4 \pm 39.8$ & 0.000 \\
\hline
\end{tabular}

\section{Duration and frequency of diarrhea}

Of 33 children with diarrhea in the intervention group, $78.8 \%$ resolved after intervention compared to $0 \%$ in 26 children in control group. The duration of diarrhea was reduced significantly in intervention group when compared to the control group. Significant differences on the severity of diarrhea were observed in intervention group after zinc supplementation compared to the control group.

Table 4. Duration and severity of diarrhea before and after intervention

\begin{tabular}{lccc}
\hline & \multicolumn{2}{c}{ Mean and standard deviation } & $\mathrm{P}$ \\
\cline { 2 - 3 } & Intervention & Control & \\
\hline $\begin{array}{l}\text { Duration of } \\
\text { diarrhea (days) }\end{array}$ & & & \\
$\quad$ Before & $4,8 \pm 3,5$ & $14,2 \pm 2,4$ & 0,454 \\
$\quad$ After & $1,7 \pm 0,8$ & $3,9 \pm 2,4$ & 0,000 \\
& & & \\
Severity of & & & \\
diarrhea (x/days) & & & \\
$\quad$ Before & $5,8 \pm 2,9$ & $5,4 \pm 2,7$ & 0,707 \\
$\quad$ After & $1,9 \pm 0,8$ & $5,3 \pm 2,6$ & 0,000 \\
\hline
\end{tabular}

The reduction in the duration and frequency of diarrhea became evident on the first week after the beginning of supplementation. There was no difference in the effect of zinc on diarrhea status according to the sex of the children.

\section{Serum zinc, TNF- $\alpha$ concentration and diarrhea}

No correlation was found between serum zinc and serum TNF- $\alpha$ concentration. Conversely, significant correlation was observed between serum zinc and fecal TNF- $\alpha$ concentration. Significant but weak correlation was observed between serum zinc concentration and the duration and frequency of diarrhea. No significant correlation was observed between serum TNF- $\alpha$ concentration and the duration of diarrhea. Conversely, significant but weak correlation was found between serum TNF- $\alpha$ concentration and duration of diarrhea. Strong and significant correlation were observed between fecal TNF- $\alpha$ concentration and the duration and severity of diarrhea.

Multi-regression analyses to evaluate the relationship between of serum zinc and TNF- $\alpha$ concentration with duration and frequency of diarrhea were determined. The results showed that among other variables entering the equation. Serum zinc concentration influenced fecal TNF- $\alpha$, while fecal TNF- $\alpha$ influenced the duration and severity of diarrhea.

\section{DISCUSSION}

Supplementation of $15 \mathrm{mg}$ elemental zinc during 8 weeks of intervention reduced the duration and frequency of diarrhea in undernourished children of Makassar city. Zinc supplementation increased serum zinc concentration in the intervention group compared to the control group. However, in children with zinc deficiency at base line, the increase in zinc concentration was significantly greater. This greater effect in zinc deficient children might be due to an increase of the rate of zinc absorption in the intestine to compensate the deficiency of zinc in this group. ${ }^{12} \mathrm{It}$ seem that the initial serum zinc level differentiate those who would derive greater benefit from supplementation from those who would benefit less. The low zinc levels found in our study was caused by low intake of zinc (only $28.3 \%$ of RDA) and protein (77.4\% of RDA) and high quantity of phytate. ${ }^{13}$

In this study, high TNF- $\alpha$ concentration was observed in the study sample. In contrast to our results, several studies have reported that in zinc deficiency, cytokine production, including TNF- $\alpha$, was decreased. ${ }^{9}$ High serum concentration of TNF- $\alpha$ before intervention may be caused by metabolic impairment or inflammation response. Zinc deficiency releases TNF$\alpha$ to the circulation.

Increased zinc levels and decreased serum TNF- $\alpha$ concentration was found in both groups, however they were only significant in the intervention group. This finding indicated that zinc had greater effect on local immunity in the intestine. Results from multiregression analysis, which shows strong and significant 
influence of serum zinc levels on fecal TNF- $\alpha$ levels, but not on serum TNF- $\alpha$ levels support this idea.

Diarrhea was consistently found in children with severe zinc deficiency. 2 One of the possible mechanisms for the effect of zinc deficiency that cause diarrhea is impairment of local immune function. Animals with zinc deficiency showed that the mucosa and gutassociated-lymphoid tissue (GALT) play an important role in the local immune system of intestine.8,14 Atrophy of the mucosa is associated with abnormal local immune system, impaired intestinal absorption, transport mechanism and diarrhea. Finally, excessive losses of endogenous zinc in diarrheal fluids may contribute to zinc deficiency.

Zinc supplementation is associated with a clinically important and statistically significant overall reduction of duration and frequency of diarrhea. In this study overall reduction of $78.8 \%$ of diarrhea occurred on the first week after the beginning of supplementation. It also resulted in reducing the frequency of diarrhea. Possible mechanisms of the effect of zinc supplementation on diarrhea are reducing fecal TNF- $\alpha$ concentration and decreasing the inflammation processes.

\section{Conclusion}

A dietary supplement of $15 \mathrm{mg}$ zinc, along with food supplementation, resulted in clinically important reduction in the duration and frequency of diarrhea among undernourished children. This may be brought about by lowering fecal TNF- $\alpha$ levels which in turn, suppress the inflammation response and improved absorption in the intestine. The biological plausibility of correcting zinc deficiency in normalizing the function of cells in multiple tissues might enhance the child's ability to combat disease states.

\section{Acknowledgement}

The authors thank all subjects and their parents, the staff who cooperatively participated in this study, and Satoto and Jose Cardona for their critical review of the manuscript. The authors would especially like to thank the Social Safety Net in Health, Ministry of Health of the Republic of Indonesia for providing financial support for this research.

\section{REFERENCES}

1. Bagui AH, Sack RB, Black ER, Chowdury HR, Yunus M, Siddique K. Cell mediated immune deficiency and malnutrition are independent risk factors for persistent diarrhea in Bangladesh children. Am J Clin Nutr 1993;58:543-8

2. Sazawal S, Black ER, Bhan KM, Jalla S, Sinha K, Bhandari N. Zinc supplementation in young children with acute diarrhea in India. N Engl J Med 1995;33:839-4

3. Black ER. Therapeutic and preventive effects of zinc on serious childhood infectious diseases in developing countries. Am J Clin Nutr 1998; 68 Suppl: 467-79.

4. Hambidge KM, Krebs NF. Assessment of zinc status in man. Indian J Pediatr 1999;62:169-80.

5. Tran-Troung AQ, Ho LH, Zalewski PD. Cellular zinc fluxes and the regulation of apoptosis/gene-directed cell death. J Nutr 2000;130 Suppl:1459-66.

6. Fraker PJ, King LE, Laakko T, Vollmer LT. The dynamic link between the integrity of the immune system and zinc status. J Nutr 2000;130 Suppl:1399-406.

7. Driessen C. Induction of cytokines by zinc ions in human peripheral blood mononuclear cells and separated monocyte. Limphokine Cytokine Res 1994;13:15-20.

8. Cui L, Okada A. Nitric oxide and manifestations of lesion of skin and gastrointestinal tract in zinc deficiency. Curr Opin Nutr Metab Care 2000;3:247-52.

9. Shankar HA, Prasad AS. Zinc and immune function: The biological basis of altered resistance to infection. Am J Clin Nutr 1998; 68 Suppl:447-63.

10. R\&D System. Quantikine human TNF- $\alpha$ immunoassay for the quantitative determination of human TNF- $\alpha$. Minneapolis. 1999.

11. SPSS Inc. Statistical package for social sciences version 10.01. Michigan: The Inc.; 2000.

12. Berdanier DC. Zinc in advanced nutrition micronutrient. CRC Press; 1998.

13. Suryani A. The influence of zinc supplementation on the profile of cytokine and diarrhea in severely malnourished under-five children [dissertation]. Makassar: Univ of Hasanuddin; 2001.

14. Scott EM, Koski GK. Zinc deficiency impairs immune responses against parasitic nematode infections at intestinal and systemic sites. Am J Clin Nutr 2000;66:413418. 